\title{
Gas fermentation: cellular engineering possibilities and scale up
}

\author{
Björn D. Heijstra*, Ching Leang and Alex Juminaga
}

\begin{abstract}
Low carbon fuels and chemicals can be sourced from renewable materials such as biomass or from industrial and municipal waste streams. Gasification of these materials allows all of the carbon to become available for product generation, a clear advantage over partial biomass conversion into fermentable sugars. Gasification results into a synthesis stream (syngas) containing carbon monoxide $(\mathrm{CO})$, carbon dioxide $\left(\mathrm{CO}_{2}\right)$, hydrogen $\left(\mathrm{H}_{2}\right)$ and nitrogen $\left(\mathrm{N}_{2}\right)$. Autotrophy-the ability to fix carbon such as $\mathrm{CO}_{2}$ is present in all domains of life but photosynthesis alone is not keeping up with anthropogenic $\mathrm{CO}_{2}$ output. One strategy is to curtail the gaseous atmospheric release by developing waste and syngas conversion technologies. Historically microorganisms have contributed to major, albeit slow, atmospheric composition changes. The current status and future potential of anaerobic gas-fermenting bacteria with special focus on acetogens are the focus of this review.
\end{abstract}

Keywords: Climate change, GHG, Waste gas, Syngas, Fermentation, Gas contaminants, Carbon recycling, Carbon capture and utilization, Scale up

\section{Background}

The critical need for technologies to limit greenhouse gas (GHG) outputs and slow down warming of the Earth is rapidly accepted. Essential to this is a further improvement in global awareness of nations and generations, and their demand for sustainable technology development and products. At the same time continued questioning of polluting industry and government enforced further tightening of emission rules is essential. Sadly, 2016 marks the year the global atmospheric $\mathrm{CO}_{2}$ level, measured at Mauna Loa Observatory, permanently reached values over $400 \mathrm{ppm}$ [1]. This level is thought to have an impact extending far beyond our lifetime and the link to the increasing average global temperature is undeniable. On the 14th of November 2016 the World Meteorological Organization (WMO) reported at the 22nd session of the Conference of the Parties (COP22) United Nations global climate summit in Morocco that 2016 is on track to be the hottest year on record. The vast amount of published research on climate change is unanimous and unequivocal pointing to the carbon footprint of the expanding

\footnotetext{
*Correspondence: bjorn.heijstra@lanzatech.com

LanzaTech, Inc., 8045 Lamon Ave, Suite 400, Skokie, IL, USA
}

world population. The urgency to reduce emissions and divest from fossil fuels has been recognized by World leaders from over 190 countries who negotiated the Paris Agreement at the $21^{\text {st }}$ Conference of the Parties to the United Nations Framework Convention on climate change [2]. This agreement was signed by 174 countries on 22 April 2016 in New York and each country that ratifies the agreement will have to set emission reduction or limitation targets, known as "nationally determined contribution," or "NDC," however the targets will be voluntary [2].

\section{Available gaseous feedstocks}

A variety of large scale industrial processes generate side streams containing low to medium and high BTU (British Thermal Units) value off gases. Examples are steel mills, ferroalloy industries, refineries and chemical plants producing high $\mathrm{CO}$ containing gases with variable compositions of $\mathrm{H}_{2}, \mathrm{CO}_{2}, \mathrm{CH}_{4}$ and $\mathrm{N}_{2}$. Many of these gases are flared or preferably burned for internal energy generation within the production facility. Another large gas source, biomass gasification to generate fermentable syngas, is recognized as an alternative to lignocellulosic biomass to 
fuel conversion. Virtually any waste product can be recycled by turning this into syngas [3-6].

When derived from biomass, syngas can be variable in $\mathrm{H}_{2}(1.2-7.3 \mathrm{~mol} \%)[7,8]$ which makes this less suited for catalytic processes such as the Fischer-Tropsch Process (FTP) which require a fixed $\mathrm{H}_{2}: \mathrm{CO}$ ratio of 2:1 [9, 10]. In addition, non-lignocellulosic biomass gasification such as municipal solid waste (MSW) is another rapidly growing gas source with limited impact on land usage and a preferred technology in crowded nations. Within petrochemical refineries (syn)gas or natural gas to liquid (GTL) technologies are well developed but require high capital investment to be economically viable and compared to petroleum based fuels have high greenhouse gas (GHG) output [11]. Within petrochemical refineries several streams of 'stranded gas' often remain underutilized due to logistical and economic barriers [12]. To limit carbon emissions into the atmosphere governments are increasingly exploring regulatory incentives while planned $\mathrm{CO}_{2}$ capping can provide economic benefits [13]. New regulatory opportunities can be expected to arise, further growing the gaseous pool available for conversion by gas fermentation.

According to life cycle analysis (LCA) studies, in many of the feed stock examples mentioned above a microorganism based gas to liquid conversion could be an economically profitable proposition while simultaneously decreasing GHG emissions when compared to fossil gasoline $[14,15]$.

\section{Gas fermentation process}

The advantages of gas fermentation have been made clear in recent reviews [16-19]. The available macro gas composition determines the organisms available for conversion: autotrophic acetogenic, carboxydotrophic, and methanotrophic bacteria can fix the carbon from $\mathrm{CO}$, $\mathrm{CO}_{2}$ or $\mathrm{CH}_{4}$ containing gases, respectively. Although chemical processes are generally faster than biological conversions, the high enzymatic specificities of biological reactions result in higher product selectivity with the formation of fewer by-products.

In this review we present data from acetogens which can conserve energy through $\mathrm{CO}_{2}(\mathrm{CO})$ fixation via the Wood-Ljungdahl pathway (WLP). This is the most efficient known pathway to convert $\mathrm{CO}_{2}$ to secreted organic products $[20,21]$. The key intermediate of the WLP, acetyl-CoA, is a precursor for enzymatic production of various other organic compounds, production of which can be of commercial interest [20, 22-25].

$\mathrm{H}_{2}$ can provide an additional energy source and certain acetogens are able to grow and produce ethanol from $\mathrm{CO}_{2}$ and $\mathrm{H}_{2}$ [26], providing direct $\mathrm{CO}_{2}$ sequestration into products. Direct input of wind, hydro or solar generated electrons could further improve carbon capture utilization $(\mathrm{CCU})$ in these naturally occurring microbial cell factories. Sakimoto et all showed a remarkable biomimetic approach with direct electron input into the WLP of Moorella thermoacetica by photosensitizing these nonphotosynthetic microbes using a biological-inorganic hybrid approach. This is a true solar to chemical carbon dioxide reduction with $90 \%$ selectivity to acetate and $10 \%$ selectivity to biomass [27]. A wide variety of $\mathrm{CO}_{2}$ reduction technologies remain under development and each could have its own positive impact reducing atmospheric $\mathrm{CO}_{2}$ levels [28-31].

A critical aspect of any fermentation involving gases as a substrate is the ability of the gas to solubilize in the liquid to a concentration that does not inhibit microbial metabolism. Inhibition can occur by the substrate being too concentrated [32] or by a low volumetric mass transfer coefficient $\left(\mathrm{k}_{\mathrm{La}}\right)$ when substrate availability can become rate-limiting. A variety of reactor configurations attempting to achieve an optimal and controllable $\mathrm{k}_{\mathrm{La}}$ have been extensively discussed in the literature: Continuous stirred tank reactors (CSTR's), bubble columns, loop reactors, immobilized beds, and hollow fiber membrane columns each have certain process dependent benefits and specific volumetric mass-transfer coefficients [4, $6,18,33-36]$.

\section{Detailed gas composition}

The wide variety of industries producing waste gas streams invariably introduce impurities due to process variables and trace elements in process feed stocks. These impurities can affect downstream conversion performance, compounds such as ash, char, tar and aromatics, lipophilic compounds that are known to accumulate into lipid bilayers affecting their functional properties [37]. Halogens and mono nitrogenous species such as hydrogen cyanide $(\mathrm{HCN})$, ammonia $\left(\mathrm{NH}_{3}\right)$, nitrogen oxide (NOx) and other known enzyme inhibiting gases such as acetylene $\left(\mathrm{C}_{2} \mathrm{H}_{2}\right)$, ethylene $\left(\mathrm{C}_{2} \mathrm{H}_{4}\right)$, ethane $\left(\mathrm{C}_{2} \mathrm{H}_{6}\right)$ and oxygen $\left(\mathrm{O}_{2}\right)$ can be present $[3,5,6,38,39]$. Sulfur compounds in the gas such as hydrogen sulfide $\left(\mathrm{H}_{2} \mathrm{~S}\right)$, carbonyl sulfide (COS), carbon disulfide $\left(\mathrm{CS}_{2}\right)$ can in turn negatively affect catalyst based scrubbing systems and their atmospheric release is restricted by environmental regulations.

For many of the above compounds commercially available scrubbing systems exist, however microbial gas fermentation as the downstream process is a relatively new addition. Monitoring optimal scrubbing system performance, including peak loads, saturation and regen cycles is critical to effectively maintain a reactive microbial population. A complete understanding of upstream process variability effect on gas contaminants production, 
together with the effect that accumulating and reactive impurities have, could reduce treatment costs. However, assuming feed gas process stability, at macro and micro composition, is an unrealistic expectation and can cause production delays at scale [40].

\section{Gas contaminant process tolerance}

A distinct advantage of the biological conversion route is that a biocatalyst is versatile, constantly renewing due to its growth rate and as a consequence also capable of adapting to its environment. The biocatalyst is therefore less susceptible to poisoning by sulfur, chlorine and tar contaminants than inorganic catalysts which in turn have a much longer residence time, and therefore exposure to, the aforementioned gas contaminants [41, 42]. However tolerance levels to certain compounds is low, $\mathrm{C}_{2} \mathrm{H}_{2}, \mathrm{HCN}$ and $\mathrm{NO}$ are considered particularly troublesome as they are known to inhibit enzymes responsible for initial harvesting of carbon and energy from syngas in acetogenic organisms [43].

Hydrogen cyanide can be formed in gasifiers fed with nitrogen containing materials, and output concentrations can be influenced by gasifier operation parameters [44, 45]. Enzyme specific tolerance has been reported where cyanide specifically interacted with Fe-hydrogenases but not with di-nuclear metal centers as found in $\mathrm{NiFe}$ or FeFe hydrogenases [39]. In another study it was found cyanide acts as a competitive inhibitor acting on the $\mathrm{Ni}-4 \mathrm{Fe}-5 \mathrm{~S}$ center of carbon monoxide dehydrogenase (CODH) [46], a key enzyme of the WLP [39, 44-47].

Besides cyanide, nitric oxide can be cogenerated in gasifiers. NO is a radical gas and used within biological systems as a transcriptional regulator [48]. At high concentrations however this reactive gas interacts within the cell to form toxic nitrogen oxides that inhibit key enzymes and at high concentrations prevent microbial growth [49]. A report on the inhibition of hydrogenase activity within a syngas operating system found tolerance levels to $40 \mathrm{ppm}$ without compromising productivity while $200 \mathrm{ppm}$ levels resulted in complete enzyme inactivation [49]. Biological tolerance can be based on conversion of $\mathrm{NO}$ to less reactive compounds such as nitrate $\left(\mathrm{NO}_{3}\right)$ nitrous oxide $\left(\mathrm{N}_{2} \mathrm{O}\right)$ or ammonia $\left(\mathrm{NH}_{3}\right)$ [48].

Acetylene dissolves well in aqueous solution, up to $47 \mathrm{mM}$ at standard conditions and is a well-known inhibitor of metalloproteins due to reversible binding to the catalytic site [50]. Acetylene can reversibly inhibit hydrogenases limiting energy generation through $\mathrm{H}_{2}$ uptake $[51,52]$. Due to the high reactivity with metalloenzymes tolerance levels are found to be low. Using $10 \%(\mathrm{v} / \mathrm{v})$ $\mathrm{C}_{2} \mathrm{H}_{2}$ fed to Rhodospirillum rubrum, it was found that CO-linked hydrogenases had 50\% reduced activity [52]. However it was found that only NiFe hydrogenases, not Fe hydrogenases, are inhibited by acetylene binding [51].
Using the rate of methanogenesis in marine sediments to study inhibitory compounds it was found acetylene irreversibly inhibits methane production while ethylene had a reversible inhibitory effect [53]. In the same study ethane was found to have no effect. Ethylene has also been described as a toxic compound to the gas fermentation process [38]. For commercialization of their gas fermentation process LanzaTech has performed extensive laboratory gas contaminant exposure tests on continuously grown Clostridium autoethanogenum cultures. Test results indicate ethylene appears to have limited to no effect on gas uptake rates in C. autoethanogenum cultures tested at up to a partial pressure of 10 mbar (Fig. 1).

For obligate anaerobic Clostridium species in industrial settings, oxygen and reactive oxygen species (ROS) are considered gas contaminants although some species are reported to withstand microoxic conditions [54-56]. In laboratory experiments on $C$. autoethanogenum under a partial pressure of up to 8 mbar oxygen an impact on $\mathrm{CO}$ utilization was measurable (Fig. 2). After reducing the oxygen concentration to 2 mbar the carbon monoxide uptake levels increased again indicating the tolerance level and reversible nature of the oxidative effect.

\section{Synthetic biology development}

Synthetic biology and metabolic engineering approaches play an essential role in expanding acetogen product spectrum beyond the native products, such as ethanol, acetate and butanediol (BDO) to other fuels and commodity chemicals. These approaches had been applied to classic model microorganisms, such as $E$. coli and yeast which have been successfully engineered to produce non-native products at commercial scale [57-60]. On the other hand, acetogenic clostridia had long been considered challenging hosts for genetic modification. The slow development of reliable molecular biology tools is partly contributed by a strong native restriction-modification

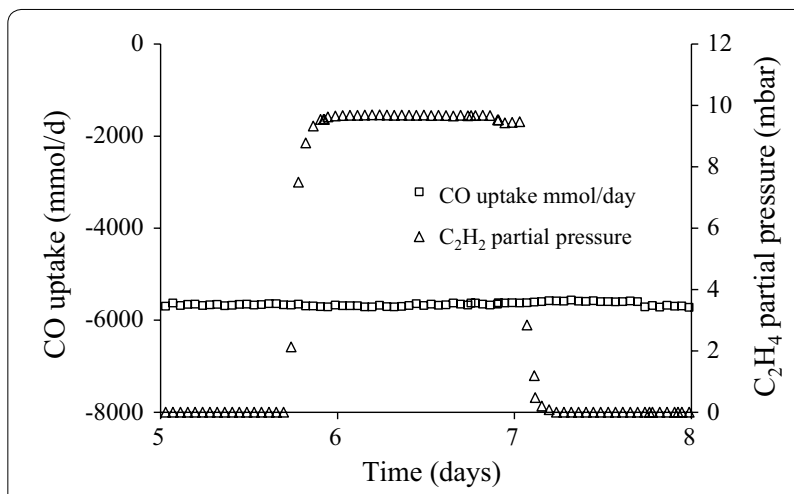

Fig. 1 CO consumption profile of a continuously operating $C$. autoethanogenum gaseous fermentation undergoing addition of ethylene by sparging with ethylene containing Nitrogen. CO consumption remains stable around $5800 \mathrm{mmol} \mathrm{CO} /$ day 


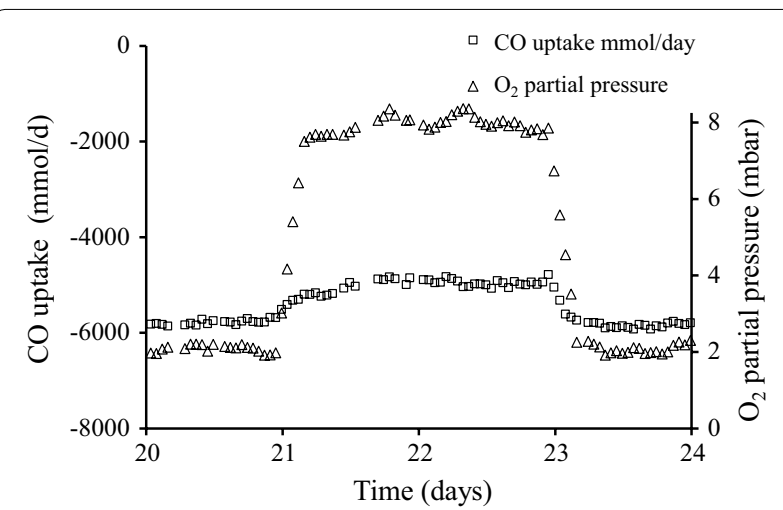

Fig. 2 CO consumption profile of a continuously operating $C$. autoethanogenum gaseous fermentation undergoing varying levels of oxygen addition. At 2 mbar oxygen concentration CO uptake is stable at approximately $5900 \mathrm{mmol} /$ day which, when oxygen is increased to $8 \mathrm{mbar}$, reaches a reversible equilibrium of $\mathrm{CO}$ uptake around $5000 \mathrm{mmol} /$ day

system, non-standard culturing conditions (toxic gas at pressure and obligate anaerobic), and slow doubling times. Since the successful demonstration of gas fermentation at pilot and pre-commercial scale as mentioned below, significant progress had been made in understanding acetogens at both the molecular and system biology levels [61-63]. Most notably, whole genome sequences, genome scale models, transcriptomic, proteomic studies and genetic tools have now been developed for these organisms. [18, 22, 26, 56, 61-71].

\section{DNA transfer}

In order to genetically modify a microorganism, whether to delete a competing pathway or to introduce a new product pathway, it is imperative to have a reliable method to introduce foreign DNA into the cell. Electroporation and conjugation are the most frequently used methods for introducing foreign DNA into acetogens [26, 62, 72]. These strategies have been successfully demonstrated in C. ljungdahlii, C. autoethangenum, C. aceticum, $A$. woodii and $M$. thermoacetica $[22,62,65,73-76]$. The highest transformation efficiency was reported to be around $1.7 \times 10^{4} \mathrm{cfu} / \mu \mathrm{g}$ DNA for $C$. ljungdahlii in acetogens and the authors successfully introduced suicide vector with homology arms for chromosomal modification $[62,77]$. Although electrocompetent cells preparation is elaborate, the method is donor cell independent, unlike conjugation. Further improvement of electroporation efficiency has been achieved through in vitro methylation or disruption of host's restriction endonuclease, such as those examples in C. acetobutylicum [78], C. pasteurianum [79] and C. cellulolyticum [80], when the methylation/restriction patterns are identified either through restriction digestion pattern identification or PacBio sequencing [79, 81, 82].

In addition, conjugation is used broadly among Clostridium species, mainly because during conjugation DNA is transferred from donor to recipient cell as a single strand, not recognizable by the recipient's restriction modification system. This method has been successfully used in C. autoethanogenum [26] and A. woodii [83]. In combination the two methods provide a robust basis platform for routine and advanced synthetic biology discovery.

\section{Genome modification}

Homologous recombination utilizing host's own recombination machinery is widely used for genome engineering. More specifically, a plasmid that carries homologous arms to the upstream and downstream areas of target gene(s), is introduced into the host. In order to select for a double crossover event (gene deletion), a positive selection (such as antibiotic resistance cassettes) or combination with a negative selection (such as mazF [84] or pyrE [85]) is used. Other variant methods that rely on homologous recombination also include Allele-Coupled Exchange (ACE) [86], Triple crossover [87] and scar-less, marker-less knockout or knock-in using two negative selection markers (C. thermocellum), detailed information has recently been reviewed [88]. In some instances, specific DNA sequences which can be recognized by sitespecific recombinases, flanking the antibiotic resistance cassettes were introduced into the chromosome at the same time during the double crossover event. The antibiotic resistance cassettes can then be excised out of the chromosome by the site-specific recombinase and produce a marker-less mutant [77].

Other genetic modification tools utilizing RNA machinery, such as the group II intron gene inactivation [89] and CRISPR/Cas9 (Clustered Regularly Interspaced Short Palindromic Repeats/CRISPR-associated protein 9), a RNA-guided prokaryotic immune system which can cleave foreign DNA [90]. The group II intron method had been applied to different Clostridium species including acetogens such as C. autoethanogenum $[26,61]$, and others [91]. This method, based on RNA-mediated, retrohoming mechanism [89], provides a quick and easy gene inactivation tool without relying on host recombination machinery, thus bypassing the low occurrence of double crossover events, and resulted in greater success in genome editing in acetogenic Clostridium. However, the nature of group II intron mutagenesis is based on insertion of the group II DNA at the target gene, therefore, this method is flawed with the possibility of polar effects on downstream genes. 
It was recently reported that the CRISPR/Cas9 system from Streptococcus pyogenes was successfully applied to acetogens, many other bacteria, and also yeast and Eukaryotes due to high and reliable efficiency, the simplicity in design and fast turnaround to generate scar-less mutants [90, 92-96]. Moreover, CRISPR/Cas9 system has been reported to target multiple genes at the same time (multiplex gene editing) [92], which allows for engineering bacterial strains with desired phenotypes in a one-step. This system has also reported to be able to edit bacterial strains at the single nucleotide level [97]. The CRISPR/Cas9 system has rapidly become the preferred method for genome editing in most organisms, facilitating rapid functional analysis and strain development for industrial applications.

\section{Genetic parts}

In addition to chromosomal editing tools, genetic parts such as promoters, terminators ribosomal binding sites (RBS) $[98,99]$ are essential for both strain and pathway development. Unlike other model microorganisms for which commercial genetic parts and even software designing tools are available, acetogens' part library is less well-developed, the majority of genetic parts such as the promoters are extracted from close Clostridium relatives or from its own genome. Recently inducible promoter systems had been successfully developed in C. ljungdahlii and C. autoethanogenum, respectively [25, 87]. It is critical to develop an organism specific validated library of genetic parts.

One limiting factor to carry out promoter screening in acetogens is the lack of fluorescent reporter protein that would allow signal to correlate with the amount of translation from a given quantity of mRNAs transcribed. So far, there has only been a flavin-based fluorescent protein derived from Pseudomonas putida that works under anaerobic conditions [100]. This has been used to characterize two endogeneous promoters of C. cellulolyticum [101]. However, it remains to be determined if this flavin-based fluorescence system will work in acetogens. Thus for most parts, promoters in acetogens are characterized using either the gusA or catP systems, encoding $\beta$-glucuronidase and chloramphenicol acetyltransferase, respectively $[25,87]$. Characterizing promoter strength, based on the enzymatic activities, is however less straightforward and time consuming.

\section{Metabolic engineering in gas fermentation}

Gas fermentation offers the benefit of not using heterologous feedstocks such as sugars that affect food supply chain. Metabolic engineering of acetogens in an industrial setting has been reviewed at length elsewhere [18]. The central metabolic pathway in acetogens begin with the reduction of $\mathrm{CO} / \mathrm{CO}_{2}$ to acetyl-CoA through the WLP. Depending on the choice of strains and feedstocks used, various native products can be produced, including acetate, ethanol, 2,3-BDO, lactate, butyrate, etc. (Table 1 in [18] and reference therein). The metabolic profiles of acetate, ethanol and 2,3-BDO produced by various industrial strains have recently been summarized [19]. At LanzaTech a proprietary process has been developed that maximizes the conversion of $\mathrm{CO}$ to ethanol in $C$. autoethanogenum using steel mill off-gas. Furthermore, it has been demonstrated that deletion of the budA gene encoding for an enzyme catalyzing 2,3-BDO production resulted in an increase in ethanol selectivity and titer as a result of diminished production of 2,3-BDO [61, 102]. The ethanol pools currently produced from the demo plants around the world have been converted into the jet fuels by the catalytic process known as alcohol-to-jet, which involves dehydration to alkenes and oligomerization to the targeted C-length [103].

To enhance process viability, the conversion of gas to more valuable products than ethanol have to be developed. There have been several reported successes in expressing heterologous pathways to produce acetone, butanol, butyrate, and isopropanol, in acetogens [22, 25]. Recent publication by the White Dog Lab even employed a co-feeding strategy, producing a mix of acetone, isopropanol, ethanol, at $12.5 \mathrm{~g} / \mathrm{L}$ in C. ljungdahlii with a combination of CO and sugar [104]. In addition to these products, LanzaTech has also developed and owns several patent families exemplifying the synthesis of higher value products such as 3-hydroxypropionic acid, methyl ethyl ketone, and mevalonate, by expressing corresponding biosynthetic pathway genes from photosynthetic bacteria Chloroflexus aurantiacus, Klebsiella, E. coli and even plant [105-108]. In most instances, the productions were demonstrated using a plasmid platform under the control of native promoter systems.

\section{Pathway and strain optimization}

In order to scale up production, pathway gene expression needs to be optimized to minimize metabolic bottlenecks and un-wanted side products [109-111]. Even though the number of publications on this topic in the field of gas fermentation is limited, many of the approaches developed through the metabolic engineering of $E$. coli and yeast are applicable to the gas fermentation organisms. In general, the strategy involves multilayers of analysis and debugging, both at the biosynthetic pathway level as well as the overall metabolic flux level of the host cells $[112,113]$. Due to the inherent complexity of a biological system, however, debugging bottlenecks one gene at a time is tedious and time consuming. Thus, it is more efficient to manipulate the gene expressions systematically, 
refactoring the biosynthetic pathway via modular design, combinatorial analysis and high-throughput screening, to identify the best combination of genes and promoters, and other transcriptional elements such as ribosomal binding sites (RBS), and terminators. [109, 114, 115]. Additionally, routine targeted proteomics and metabolomics can be performed to rapidly assess gene expressions and key metabolites accumulation [116-119]. With the technologies developed in the field of synthetic biology for the past 10 years, including computer-aided pathway design algorithms [120-122], DNA assembly and sequencing [123-125], it is now routine to screen a large combinatorial libraries. When combined with rational design and effective screening methodologies, the combinatorial library facilitates the search for ideal pathway combinations for highly productive strains [126, 127].

\section{Use of omics based technology to monitor bioprocess performance}

Nextgen sequencing has become a powerful tool in process optimization. Routine sequence analysis at genomic and transcriptomic levels are carried out to determine gene expression and mutation rate, which directly relate to process productivity and stability at molecular level. One recent study linked the genomic and metabolic analysis of various acetogens to confirm the involvement of the acetaldehyde oxidoreductase (AOR) in ethanol production and NADPH-dependent alcohol dehydrogenase $(\mathrm{ADH})$ in the hydration of acetone to isopropanol in acetogens [19]. Moreover, C. autoethanogenum has been the subject of a multi-omics investigation to compare energy metabolism between autotrophic and heterotrophic growth [61]. The study highlighted the interplay of hydrogenases and the electron-bifurcating Nfn complex in ethanol formation during the autotrophic growth. The study also concluded that the overall energy yield does not change during the autotrophic or heterotrophic growth. The vast data provided by omics analysis from production plants, can be used to further improve pathway and strain design.

Metabolic flux analysis is often used in conjunction to the omics analyses to debug bottlenecks through the metabolic flux of interest [128]. A metabolic flux analysis on the syngas species, Clostridium tyrobutyricum, correlated increase in NADH with increase in butanol production [129, 130]. Moreover, genome-scale metabolic flux balance analysis has been used to construct spatiotemporal metabolic models for Clostridium ljungdahlii [131]. When combined with the Optknock computation, the models could predict new gene knockout targets relevant to the overproduction of ethanol, lactate and 2,3-BDO in a bubble column reactor [132].

\section{Scale-up}

As described above the research output in the gas fermentation field and the synthetic biology capabilities on its subject microorganisms have been rapidly expanding. However, in 2016 two of the three companies that own and operate scaled up gas fermentation facilities suspended operations. This immediately raises the question whether gas fermentation is scalable. Below we briefly summarize what is known about these three companies and for the first time present gas fermentation production data from a LanzaTech demonstration facility located within a steel mill plant in China.

Three companies, Coskata, INEOS Bio, and LanzaTech have operated pilot and demonstration plants for extended periods of time. Coskata's technology reformed methane into syngas with a $\mathrm{H}_{2}$ : $\mathrm{CO}$ ratio of between 2:1 and 3:1, followed by fermentation of this syngas to ethanol. This approach seeks to take advantage of the current low price of natural gas in geographies such as the US. While Coskata announced that it was to cease operation in 2015, the technology developed in this company now forms the basis of a new company: Synata Bio [133].

INEOS recently announced it is selling the INEOS Bio facility in Vero Beach, FL, USA [134]. This name-plate 8 million gallon per year (Mgy) semi-commercial facility was built as a joint venture with New Planet Energy Holdings, LLC. Commissioned in 2012, the facility used lignocellulosic biomass and MSW for generating syngas and coproduced $6 \mathrm{MW}$ of electrical power. In July 2013 the company announced successful production of ethanol at its facility [135]. In September 2014 operational changes were imposed to optimize the technology and de-bottleneck the plant to achieve full production capacity [40].

\section{LanzaTech}

LanzaTech was founded in 2005 and after extensive piloting at a modest capacity steel mill plant in New Zealand, it partnered with 2 larger Chinese steel mills to build gas fermentation demonstration facilities. The first Demonstration unit was located at one of BaoSteel's mills near Shanghai (operational since 2012) and the second at a Shougang steel mill near Beijing (operational since 2013), both facilities have a 100,000 gpy pre-commercial capacity. Typical production results from the second facility (Fig. 3) are shown below. To our knowledge this is the first time continuous, long term gas fermentation production data has been published from a demonstration facility. It is important to note this facility is running directly off steel mill produced off-gas and operational set-ups are a reality of scaled up operations. The gas fermentation process has proven robust to a wide variety of process upsets such as: macro gas concentration 


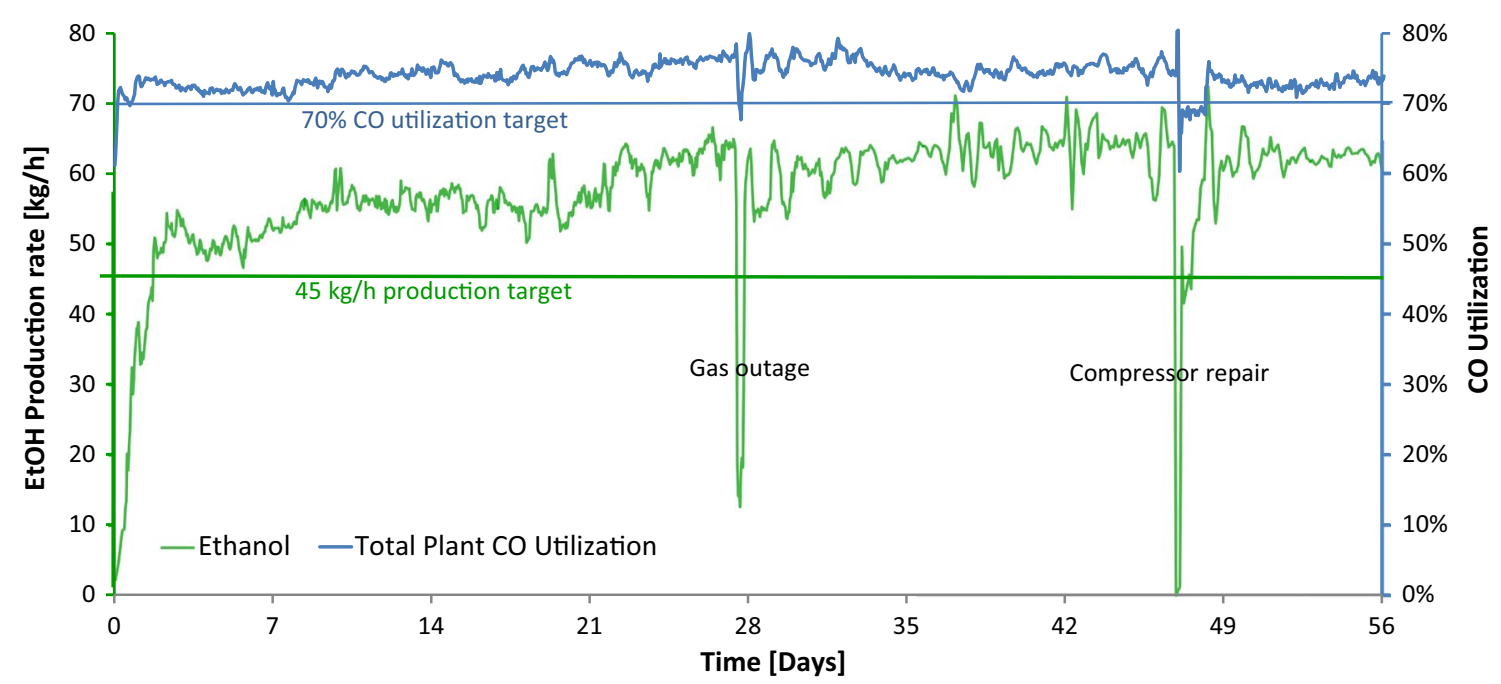

Fig. 3 Ethanol production and carbon monoxide utilization profiles over an 8 week period. Data collected at the Beijing Shougang LanzaTech New Energy Science \& Technology Co., Ltd, a 0.1 Mgy ethanol capacity demonstration facility

fluctuations, presence of gas contaminants, intermittent gas supply and equipment failure which can be replaced during the continuous fermentation.

The Shougang facility earned the Roundtable on Sustainable Biomaterials (RSB) certification for sustainability [136]. The RSB is the most robust and credible global sustainability standard and certification system for biofuels and biomaterials production. Here we present production and gas utilization data from a typical run from the RSB certified plant. The resulting ethanol from the LanzaTech Demo facilities has been turned into jet fuel ready for a test flight scheduled for 2017 [137].

In 2015, both China Steel Corporation of Taiwan and ArcelorMittal of Luxembourg approved commercial projects with LanzaTech. The former will be a $17 \mathrm{Mgy}$ facility with the intention to scale up to 34 Mgy [138]. The latter 21 Mgy facility will be built at ArcelorMittal's flagship steel plant in Ghent, Belgium with intention to construct further plants across ArcelorMittal's operations [139]. If scaled up to its full potential at steel mills in Europe alone, the technology could enable the production of around $104 \mathrm{Mgy}$ with the potential to displace 1.6 million barrels of fossil fuel-derived gasoline on a BTU basis.

\section{Summary and outlook}

Gas fermentation is rapidly becoming an established platform for the conversion of (waste) gas to valuable liquid chemicals. Clear advantages are process stability and tolerance to inhibitory compounds and therefore flexibility in gas feedstock sourcing. Process upsets, either upstream or downstream can occur with limited warning at scaled up operations. Resilience of the microbial culture to upsets can be enhanced by engineering design to limit their impact. The production of ethanol has been proven robust at scaled up operations, the next stage is now set for expanding the product portfolio utilizing advanced synthetic biology technologies developed for gas fermenting microorganisms. This allows for a profitable carbon recycling operation, producing sustainable chemicals independent of carbon credits, to further limit GHG emission. With an industrially robust strain, efficient genetic toolbox, advanced synthetic biology capabilities, and scalable reactor design, the field of gas fermentation remains on course to reduce global carbon emissions.

\section{Authors' contributions}

AJ and $\mathrm{CL}$ wrote synbio sections, BH wrote gaseous feedstocks, scale up and prepared figures. All authors edited the complete manuscript. All authors read and approved the final manuscript.

\section{Acknowledgements}

We thank the complete and dedicated team involved at the Beijing Shougang LanzaTech New Energy Science \& Technology Co., Ltd. for the scaled up fermentation data presented in Fig. 3. We thank Melvin Moore and Steven Glasker for data gathered in Figs. 1 and 2.

\section{Competing interests}

The authors declare that the review was written in the absence of any commercial or financial relationships that could be construed as a potential competing interests.

LanzaTech, Inc has commercial interest in gas fermentation.

\section{Availability of data and materials}

The datasets provided within this review are not publicly available due to commercial sensitivity but are available from the corresponding author on reasonable request. 


\section{Consent for publication}

Given by LanzaTech Inc and all three authors.

\section{Funding}

We thank the following investors in LanzaTech's technology: Sir Stephen Tindall, Khosla Ventures, Qiming Venture Partners, Softbank China, the Malaysian Life Sciences Capital Fund, Mitsui, Primetals, CICC Growth Capital Fund I, L.P. and the New Zealand Superannuation Fund.

\section{Publisher's Note}

Springer Nature remains neutral with regard to jurisdictional claims in published maps and institutional affiliations.

Received: 18 November 2016 Accepted: 4 April 2017

Published online: 12 April 2017

\section{References}

1. Kahn B. The world passes 400 PPM threshold permanently. Clim Cent. http://www.climatecentral.org/news/ world-passes-400-ppm-threshold-permanently-20738.

2. United Nations. Adoption of the Paris agreement. 2015;21932:32. http:// unfccc.int/resource/docs/2015/cop21/eng/l09r01.pdf.

3. Griffin DW, Schultz MA. Fuel and chemical products from biomass syngas: a comparison of gas fermentation to thermochemical conversion routes. Environ Prog Sustain Energy. 2012;31:219-24.

4. Munasinghe PC, Khanal SK. Syngas fermentation to biofuel: evaluation of carbon monoxide mass transfer and analytical modeling using a composite hollow fiber (CHF) membrane bioreactor. Bioresour Technol. 2012;122:130-6.

5. Munasinghe PC, Khanal SK. Biomass-derived syngas fermentation into biofuels: opportunities and challenges. Bioresour Technol. 2010;101:5013-22.

6. Abubackar HN, Veiga MC, Kennes C, Coruña L. Biological conversion of carbon monoxide: rich syngas or waste gases to bioethanol. Biofuels Bioprod Biorefining. 2011;5:93-114.

7. Boateng A, Banowetz G, Steiner J, Barton T, Taylor D, Hicks K, et al. Gasification of Kentucky bluegrass (Poa pratensis I.) straw in a farm-scale reactor. Biomass Bioenergy. 2007;31:153-61.

8. Datar RP, Shenkman RM, Cateni BG, Huhnke RL, Lewis RS. Fermentation of biomass-generated producer gas to ethanol. Biotechnol Bioeng. 2004;86:587-94

9. Maitlis PM, de KlerkA. Greener Fischer-Tropsch processes for fuels and Feedstocks. Greener Fischer-Tropsch process. Fuels feed. New York: Wiley; 2013.

10. de Klerk A, Li YW, Zennaro R. Fischer-Tropsch technology. Greener Fischer-Tropsch process. Fuels feed. New York: Wiley; 2013. p. 53-79.

11. Jaramillo P, Griffin WM, Matthews HS. Comparative analysis of the production costs and life-cycle GHG emissions of FT liquid fuels from coal and natural gas. Environ Sci Technol. 2008;42:7559-65.

12. Thackeray F, Leckie G. Stranded gas: a vital resource. Pet Econ. 2002;69(5):10-2.

13. Glomsrød S, Wei T, Aamaas B, Lund MT, Samset BH. A warmer policy for a colder climate: can China both reduce poverty and cap carbon emissions? Sci Total Environ. 2016;568:236-44.

14. Handler RM, Shonnard D, Palou-Rivera I, Lai A, Hallen RT, Zhu Y, et al. Life cycle assessments of jet fuel and co-products made from lanzatech biomass-based ethanol. AlChE Natl Meet. 2014.

15. Handler RM, Shonnard DR, Griffing EM, Lai A, Palou-Rivera I. Life cycle assessments of ethanol production via gas fermentation: anticipated greenhouse gas emissions for cellulosic and waste gas feedstocks. Ind Eng Chem Res. 2016;55:3253-61.

16. Lee SH, Kim HJ, Shin YA, Kim KH, Lee SJ. Single crossover-mediated markerless genome engineering in Clostridium acetobutylicum. J Microbiol Biotechnol. 2016;26(4):725-9.

17. Molitor B, Richter H, Martin ME, Jensen RO, Juminaga A, Mihalcea C, et al. TEMPORARY REMOVAL: Carbon recovery by fermentation of COrich off gases-turning steel mills into biorefineries. Bioresour Technol. 2016. (In press).
18. Liew F, Martin E, Tappel R, Heijstra B, Mihalcea C, Köpke M. Gas fermentation-a flexible platform for commercial scale production of low carbon fuels and chemicals from waste and renewable feedstocks. Front Microbiol. 2016;7:694.

19. Bengelsdorf FR, Poehlein A, Linder S, Erz C, Hummel T, Hoffmeister S, et al. Industrial acetogenic biocatalysts: a comparative metabolic and genomic analysis. Front Microbiol. 2016;7:1-15.

20. Tracy BP, Jones SW, Fast AG, Indurthi DC, Papoutsakis ET. Clostridia: the importance of their exceptional substrate and metabolite diversity for biofuel and biorefinery applications. Curr Opin Biotechnol. 2011;23:1-18.

21. Fast AG, Papoutsakis ET. Stoichiometric and energetic analyses of nonphotosynthetic $\mathrm{CO}_{2}$-fixation pathways to support synthetic biology strategies for production of fuels and chemicals. Curr Opin Chem Eng. 2012;7:1-16.

22. Köpke M, Held C, Hujer S, Liesegang H, Wiezer A, Wollherr A, et al. Clostridium ljungdahlii represents a microbial production platform based on syngas. Proc Natl Acad Sci USA. 2010;107:13087-92.

23. Drake HL, Küsel K, Matthies C, Wood HG, Ljungdahl LG. Acetogenic Prokaryotes. In: Dworkin M, Falkow S, Rosenberg E, Schleifer K-H, Stackebrandt E, editors. The Prokaryotes. 3rd ed. New York: Springer; 2006. p. 354-420.

24. Köpke M, Mihalcea C, Liew F, Tizard JH, Ali MS, Conolly JJ, et al. 2,3-butanediol production by acetogenic bacteria, an alternative route to chemical synthesis, using industrial waste gas. Appl Environ Microbiol. 2011;77:5467-75.

25. Banerjee A, Leang C, Ueki T, Nevin KP, Lovley DR. A lactose-inducible system for metabolic engineering of Clostridium ljungdahlii. Appl Environ Microbiol. 2014;80:2410-6.

26. Mock J, Zheng Y, Mueller AP, Ly S, Tran L, Segovia S, et al. Energy conservation associated with ethanol formation from $\mathrm{H}_{2}$ and $\mathrm{CO}_{2}$ in Clostridium autoethanogenum involving electron bifurcation. J Bacteriol. 2015;197:2965-80

27. Sakimoto KK, Wong AB, Yang P. Self-photosensitization of nonphotosynthetic bacteria for solar-to-chemical production. Science (80-). 2016;351:74-7.

28. Zhao Z, Zhang Y, Li Y, Zhao H, Quan X. Electrochemical reduction of carbon dioxide to formate with Fe-C electrodes in anaerobic sludge digestion process. Water Res. 2016;106:339-43.

29. Bajracharya S, Vanbroekhoven K, Buisman CJN, Pant D, Strik DP. Application of gas diffusion biocathode in microbial electrosynthesis from carbon dioxide. Environ Sci Pollut Res. 2016;23:22292-308.

30. Kattel S, Yan B, Yang Y, Chen JG, Liu P. Optimizing binding energies of key intermediates for $\mathrm{CO}_{2}$ hydrogenation to methanol over oxidesupported copper. J Am Chem Soc. 2016:138:12440-50.

31. Buelens LC, Galvita W, Poelman H, Detavernier C, Marin GB. Superdry reforming of methane intensifies $\mathrm{CO}_{2}$ utilization via Le Chatelier's principle. Science. 2016;354:449-52.

32. Bertsch J, Muller V. CO metabolism in the acetogen Acetobacterium woodii. Appl Environ Microbiol. 2015:81:5949-56.

33. Bredwell MD, Srivastava P, Worden RM. Reactor design issues for synthesis-gas fermentations. Biotechnol Prog. 1999:15:834-44.

34. Kimmel DE, Klasson KT, Clausen EC, Gaddy JL. Performance of trickle-bed bioreactors for converting synthesis gas to methane. Appl Biochem Biotechnol. 1991;28-29:457-69.

35. Orgill J Atiyeh HK, Devarapalli M, Phillips JR, Lewis RS, Huhnke RL. A comparison of mass transfer coefficients between trickle-bed, hollow fiber membrane and stirred tank reactors. Bioresour Technol. 2013;133:340-6.

36. Ungerman AJ, Heindel TJ. Carbon monoxide mass transfer for syngas fermentation in a stirred tank reactor with dual impeller configurations. Biotechnol Prog. 2007;23:613-20.

37. Sikkema J, de Bont JA, Poolman B. Mechanisms of membrane toxicity of hydrocarbons. Microbiol Rev. 1995;59:201-22.

38. Zahn J. Scale-up of renewable chemical Manufacturing processes Recent Adv Ferment Technol. 2015. https://sim.confex.com/sim/raft11/ webprogram/Paper31231.html.

39. Shima S, Ataka K. Isocyanides inhibit [Fe]-hydrogenase with very high affinity. FEBS Lett. 2011;585:353-6.

40. Lane J. On the mend: Why INEOS Bio isn't producing ethanol in Florida. Biofuels Dig. 2014. http://www.biofuelsdigest.com/bdigest/2014/09/05/ on-the-mend-why-ineos-bio-isnt-reporting-much-ethanol-production/. 
41. Köpke M, Noack S, Dürre P. The past, present, and future of biofuels-biobutanol as promising alternative. Biofuel Prod Dev Prospect. 2011;451-86. http://www.intechopen.com/articles/show/title/the-pastpresent-and-future-of-biofuels-biobutanol-as-promising-alternative.

42. Mohammadi M, Najafpour GD, Younesi H, Lahijani P, Uzir MH, Mohamed AR. Bioconversion of synthesis gas to second generation biofuels: a review. Renew Sustain Energy Rev. 2011;15(9):4255-73.

43. Wang VC, Can M, Pierce E, Ragsdale SW, Armstrong FA. A unified electrocatalytic description of the action of inhibitors of nickel carbon monoxide dehydrogenase. J Am Chem Soc. 2013;135:2198-206.

44. Paterson N, Zhuo Y, Dugwell D, Kandiyoti R. Formation of hydrogen cyanide and ammonia during the gasification of sewage sludge and bituminous coal. Energy Fuels. 2005;19:1016-22.

45. Lin J-Y, Zhang S, Zhang L, Min Z, Tay H, Li C-Z. HCN and NH3 formation during coal/char gasification in the presence of NO. Environ Sci Technol. 2010;44:3719-23.

46. Ha SW, Korbas M, Klepsch M, Meyer-Klaucke W, Meyer O, Svetlitchnyi V. Interaction of potassium cyanide with the [Ni-4Fe-5S] active site cluster of CO dehydrogenase from Carboxydothermus hydrogenoformans. J Biol Chem. 2007:282:10639-46.

47. Ragsdale SW, Ljungdahl LG, DerVartanian DV. Isolation of carbon monoxide dehydrogenase from Acetobacterium woodii and comparison of its properties with those of the Clostridium thermoaceticum enzyme. J Bacteriol. 1983;155:1224-37.

48. Stern AM, Zhu J. An introduction to nitric oxide sensing and response in bacteria. Adv Appl Microbiol. 2014. doi:10.1016/ B978-0-12-800261-2.00005-0.

49. Ahmed A, Lewis RS. Fermentation of biomass-generated synthesis gas: effects of nitric oxide. Biotechnol Bioeng. 2007;97:1080-6.

50. Hyman MR, Daniel A. Acetylene inhibition of metalloenzymes. Anal Biochem. 1988;173:207-20.

51. He SH, Woo SB, DerVartanian DV, Le Gall J, Peck HD. Effects of acetylene on hydrogenases from the sulfate reducing and methanogenic bacteria. Biochem Biophys Res Commun. 1989;161:127-33.

52. Maness PC, Weaver PF. Evidence for three distinct hydrogenase activities in Rhodospirillum rubrum. Appl Microbiol Biotechnol. 2001;57:751-6.

53. Oremland RS, Taylor BF. Inhibition of methanogenesis in marine sediments by acetylene and ethylene: validity of the acetylene reduction assay for anaerobic microcosms. Appl Microbiol. 1975;30:707-9.

54. Karnholz A, Kusel K, Goner A, Schramm A, Drake HL, Küsel K, et al. Tolerance and metabolic response of acetogenic bacteria toward oxygen. Appl Environ Microbiol. 2002;68:1005-9.

55. Kawasaki S, Sakai Y, Takahashi T, Suzuki I, Niimura Y. $\mathrm{O}_{2}$ and reactive oxygen species detoxification complex, composed of $\mathrm{O}_{2}$-responsive $\mathrm{NADH}$ :rubredoxin oxidoreductase-flavoprotein A2-desulfoferrodoxin operon enzymes, rubperoxin, and rubredoxin, in Clostridium acetobutylicum. Appl Environ Microbiol. 2009;75:1021-9.

56. Whitham JM, Tirado-Acevedo O, Chinn MS, Pawlak JJ, Grunden AM. Metabolic response of Clostridium ljungdahlii to oxygen exposure. Appl Environ Microbiol. 2015;81:AEM.02491.

57. Yim H, Haselbeck R, Niu W, Pujol-Baxley C, Burgard A, Boldt J, et al. Metabolic engineering of Escherichia coli for direct production of 1,4-butanediol. Nat Chem Biol. 2011;7:445-52.

58. Haselbeck R, Trawick JD, Niu W, Burgard AP. Microorganisms for the production of 1,4-butanediol, 4-hydroxybutanal, 4-hydroxybutyryl-coa, putrescine and related compounds, and methods related thereto. US 20110229946 A1. 2011.

59. Paddon CJ, Keasling JD. Semi-synthetic artemisinin: a model for the use of synthetic biology in pharmaceutical development. Nat Rev Microbiol. 2014;12:355-67.

60. Lane J. Amyris inks 5-year $\$ 100 \mathrm{M}+$ biofene supply pact for nutraceutical market. Biofuels Dig. 2016. http://www.biofuelsdigest.com/ bdigest/2016/04/28/amyris-inks-5-year-100m-biofene-supply-pactfor-nutraceutical-market/.

61. Marcellin E, Behrendorff JB, Nagaraju S, DeTissera S, Segovia S, Palfreyman $\mathrm{R}$, et al. Low carbon fuels and commodity chemicals from waste gases-systematic approach to understand energy metabolism in a model acetogen. Green Chem. 2016;18:3020-8.

62. Leang C, Ueki T, Nevin KP, Lovley DR. A genetic system for Clostridium ljungdahlii: a chassis for autotrophic production of biocommodities and a model homoacetogen. Appl Environ Microbiol. 2013;79:1102-9.
63. Nagarajan H, Sahin M, Nogales J, Latif H, Lovley DR, Ebrahim A, et al. Characterizing acetogenic metabolism using a genome-scale metabolic reconstruction of Clostridium ljungdahlii. Microb Cell Fact. 2013;12:118.

64. Utturkar SM, Klingeman DM, Bruno-Barcena JM, Chinn MS, Grunden AM, Köpke $M$, et al. Sequence data for Clostridium autoethanogenum using three generations of sequencing technologies. Sci Data. 2015;2:150014.

65. Poehlein A, Cebulla M, Ilg MM, Bengelsdorf FR, Schiel-Bengelsdorf $B$, Whited $\mathrm{G}$, et al. The complete genome sequence of Clostridium aceticum: a missing link between rnf- and cytochrome-containing autotrophic acetogens. MBio. 2015;6:e01168.

66. Poehlein A, Schmidt S, Kaster A-K, Goenrich M, Vollmers J, Thürmer A, et al. An ancient pathway combining carbon dioxide fixation with the generation and utilization of a sodium ion gradient for ATP synthesis. PLOS ONE. 2012;7:e33439.

67. Pierce E, Xie G, Barabote RD, Saunders E, Han CS, Detter JC, et al. The complete genome sequence of Moorella thermoacetica ( $f$. Clostridium thermoaceticum). Environ Microbiol. 2008;10:2550-73.

68. Roh H, Ko HJ, Kim D, Choi DG, Park S, Kim S, et al. Complete genome sequence of a carbon monoxide-utilizing acetogen, Eubacterium limosum KIST612. J Bacteriol. 2011;193:307-8.

69. Tan Y, Liu J, Chen X, Zheng H, Li F. RNA-seq-based comparative transcriptome analysis of the syngas-utilizing bacterium Clostridium ljungdahlii DSM 13528 grown autotrophically and heterotrophically. Mol BioSyst. 2013;9:2775-84.

70. Islam MA, Zengler K, Edwards EA, Mahadevan R, Stephanopoulos G. Investigating Moorella thermoacetica metabolism with a genome-scale constraint-based metabolic model. Integr Biol (Camb). 2015;7:869-82.

71. Brown SD, Nagaraju S, Utturkar S, De Tissera S, Segovia S, Mitchell W, et al. Comparison of single-molecule sequencing and hybrid approaches for finishing the genome of Clostridium autoethanogenum and analysis of CRISPR systems in industrial relevant Clostridia. Biotechnol Biofuels. 2014;7:40.

72. Strätz M, Sauer U, Kuhn A, Dürre P. Plasmid transfer into the homoacetogen Acetobacterium woodii by electroporation and conjugation. Appl Environ Microbiol. 1994;60:1033-7.

73. Köpke M, Liew F. Recombinant microorganisms and methods for production thereof. US 2011/0236941A1. 2011

74. Straub M, Demler M, Weuster-Botz D, Dürre P. Selective enhancement of autotrophic acetate production with genetically modified Acetobacterium woodii. J Biotechnol. 2014;178:67-72.

75. Schiel-Bengelsdorf B, Dürre P. Pathway engineering and synthetic biology using acetogens. FEBS Lett. 2012;586:2191-8.

76. Kita A, Iwasaki Y, Sakai S, Okuto S, Takaoka K, Suzuki T, et al. Development of genetic transformation and heterologous expression system in carboxydotrophic thermophilic acetogen Moorella thermoacetica. J Biosci Bioeng. 2013;115:347-52.

77. Ueki T, Nevin KP,Woodard TL, Lovley DR. Converting carbon dioxide to butyrate with an engineered strain of Clostridium ljungdahlii. MBio. 2014;5.

78. Mermelstein LD, Papoutsakis ET. In vivo methylation in Escherichia coli by the Bacillus subtilis phage ?3T I methyltransferase to protect plasmids from restriction upon transformation of Clostridium acetobutylicum ATCC 824. Appl Environ Microbiol. 1993;59:1077-81.

79. Pyne ME, Moo-Young M, Chung DA, Chou CP. Development of an electrotransformation protocol for genetic manipulation of Clostridium pasteurianum. Biotechnol Biofuels. 2013;6:50.

80. Cui GZ, Hong W, Zhang J, Li WL, Feng Y, Liu YJ, et al. Targeted gene engineering in Clostridium cellulolyticum $\mathrm{H} 10$ without methylation. J Microbiol Methods. 2012;89:201-8.

81. Clark TA, Murray IA, Morgan RD, Kislyuk AO, Spittle KE, Boitano M, et al. Characterization of DNA methyltransferase specificities using singlemolecule, real-time DNA sequencing. Nucleic Acids Res. 2012;40:e29.

82. Murray IA, ClarkTA, Morgan RD, Boitano M, Anton BP, Luong K, et al. The methylomes of six bacteria. Nucleic Acids Res. 2012;40:11450-62.

83. Stratz M, Sauer U, Kuhn A, Durre P. Plasmid transfer into the homoacetogen Acetobacterium woodii by electroporation and conjugation. Appl Environ Microbiol. 1994;60:1033-7.

84. Al-Hinai MA, Fast AG, Papoutsakis ET. Novel system for efficient isolation of Clostridium double-crossover allelic exchange mutants enabling markerless chromosomal gene deletions and DNA integration. Appl Environ Microbiol. 2012;78:8112-21. 
85. Ng YK, Ehsaan M, Philip S, Collery MM, Janoir C, Collignon A, et al. Expanding the repertoire of gene tools for precise manipulation of the clostridium difficile genome: allelic exchange using pyrE alleles. PLoS ONE. 2013;8:e56051.

86. Heap JT, Ehsaan M, Cooksley CM, Ng Y-K, Cartman ST, Winzer K, et al. Integration of DNA into bacterial chromosomes from plasmids without a counter-selection marker. Nucleic Acids Res. 2012;40:e59.

87. Walker DJF, Koepke M. Method of producing a recombinant microorganism. US9315830B2. 2016

88. Liew FM, Martin ME, Tappel RC, Heijstra BD, Mihalcea C, Köpke M. Gas fermentation-a flexible platform for commercial scale production of low-carbon-fuels and chemicals from waste and renewable feedstocks. Front Microbiol. 2016;7:694.

89. Lambowitz AM, Zimmerly S. Mobile group II introns. Annu Rev Genet. 2004;38:1-35.

90. Mei Y, Wang Y, Chen H, Sun ZS, Da JuX. Recent progress in CRISPR/Cas9 technology. J Genet Genom. 2016;43:63-75.

91. Heap JT, Pennington OJ, Cartman ST, Carter GP, Minton NP. The ClosTron: a universal gene knock-out system for the genus Clostridium. J Microbiol Methods. 2007;70:452-64.

92. Jiang Y, Chen B, Duan C, Sun B, Yang J, Yang S. Multigene editing in the Escherichia coli genome via the CRISPR-Cas9 system. Appl Environ Microbiol. 2015;81:2506-14.

93. Jiang Wenyan, Bikard David, Cox David. Feng Zhang and LAM. CRISPRassisted editing of bacterial genomes. Nat Biotechnol. 2013;31:233-9.

94. Dicarlo JE, Norville JE, Mali P, Rios X, Aach J, Church GM. Genome engineering in Saccharomyces cerevisiae using CRISPR-Cas systems. Nucleic Acids Res. 2013;41:4336-43.

95. Huang H, Chai C, Li N, Rowe P, Minton NP, Yang S, et al. CRISPR/Cas9based efficient genome editing in Clostridium ljungdahlii, an autotrophic gas-fermenting bacterium. ACS Synth Biol. 2016. doi:10.1021/ acssynbio.6b00044.

96. Nagaraju S, Davies NK, Walker DJF, Köpke M, Simpson SD. Genome editing of Clostridium autoethanogenum using CRISPR/Cas9. Biotechnol Biofuels. 2016;9:219.

97. Wang Y, Zhang ZT, Seo SO, Lynn P, Lu T, Jin YS, et al. Bacterial genome editing with CRISPR-Cas9: deletion, Integration, single nucleotide modification, and desirable "clean" mutant selection in Clostridium beijerinckii as an example. ACS Synth Biol. 2016;5:721-32.

98. Salis HM, Mirsky EA, Voigt CA. Automated design of synthetic ribosome binding sites to control protein expression. Nat Biotechnol. 2009;27:946-50.

99. Salis HM. The ribosome binding site calculator. Methods Enzymol. 2011;498:19-42.

100. Mukherjee A, Schroeder CM. Flavin-based fluorescent proteins: emerging paradigms in biological imaging. Curr Opin Biotechnol. 2015;31:16-23.

101. Teng L, Wang K, Xu J, Xu C. Flavin mononucleotide (FMN)-based fluorescent protein (FbFP) as reporter for promoter screening in Clostridium cellulolyticum. J Microbiol Methods. 2015;119:37-43.

102. Köpke M, Nagaraju S, Chen W. Recombinant microorganisms and methods of use thereof. WO 2013/115659 A2. 2013

103. Heveling J, Nicolaides CP, Scurrell MS. Catalysts and conditions for the highly efficient, selective and stable heterogeneous oligomerisation of ethylene. Appl Catal A Gen. 1998;173:1-9.

104. Jones SW, Fast AG, Carlson ED, Wiedel CA, Au J, Antoniewicz MR, et al. $\mathrm{CO}_{2}$ fixation by anaerobic non-photosynthetic mixotrophy for improved carbon conversion. Nat Commun. 2016;7:12800.

105. Köpke M, Gerth ML, Maddock DJ, Mueller AP, Liew F, Simpson SD, et al. Reconstruction of an acetogenic 2,3-butanediol pathway involving a novel NADPH-dependent primary-secondary alcohol dehydrogenase. Appl Environ Microbiol. 2014;80:3394-403.

106. Köpke $M$, Chen WY. Recombinant microorganisms and uses therefor. US20130323806 A1. 2013.

107. Mueller A, Koepke M, Nagaraju S. Recombinant microorganisms and uses therefor. US20130330809 A1. 2013.

108. Liew FM, Köpke M, Simpson SD. Gas fermentation for commercial biofuels production. In: Fang Z, editor. Biofuel Prod Dev Prospect. Rijeka: InTech; 2013. p. 125-74.

109. Boock JT, Gupta A, Prather KLJ. Screening and modular design for metabolic pathway optimization. Curr Opin Biotechnol. 2015;36:189-98.
110. Keasling JD. Manufacturing molecules through metabolic engineering. Science. 2010; 330:1355-8.

111. Stephanopoulos G. Metabolic fluxes and metabolic engineering. Metab Eng. 1999;1:1-11.

112. Lechner A, Brunk E, Keasling JD. The need for integrated approaches in metabolic engineering. Cold Spring Harb Perspect Biol. 2016;8:a023903.

113. Barton NR, Burgard AP, Burk MJ, Crater JS, Osterhout RE, Pharkya P, et al. An integrated biotechnology platform for developing sustainable chemical processes. J Ind Microbiol Biotechnol. 2015;42:349-60.

114. Biggs BW, De Paepe B, Santos CNS, De Mey M, Kumaran Ajikumar P. Multivariate modular metabolic engineering for pathway and strain optimization. Curr Opin Biotechnol. 2014;29:156-62.

115. Liu W, Jiang R. Combinatorial and high-throughput screening approaches for strain engineering. Appl Microbiol Biotechnol. 2015;99:2093-104.

116. Landels A, Evans C, Noirel J, Wright PC. Advances in proteomics for production strain analysis. Curr Opin Biotechnol. 2015;35:111-7.

117. Brunk E, George KW, Alonso-Gutierrez J, Keasling JD, Palsson BO, Lee TS, et al. Characterizing strain variation in engineered $E$. coli using a multiomics-based workflow. Cell Syst. 2016;2:335-46.

118. Baidoo EE, Benke PI, Keasling JD. Mass spectrometry-based microbial metabolomics. Microb Syst Biol Methods Prot. 2012. doi:10.1007/978-1-61779-827-6_9.

119. Batth TS, Singh P, Ramakrishnan VR, Sousa MML, Chan LJG, Tran HM, et al. A targeted proteomics toolkit for high-throughput absolute quantification of Escherichia coli proteins. Metab Eng. 2014;26:48-56.

120. Oberortner E, Densmore D. Web-based software tool for constraintbased design specification of synthetic biological systems. ACS Synth. Biol. 2015:4:757-60.

121. Hillson NJ. j5 DNA assembly design automation. Methods Mol Biol. 2014; 1116:245-69. doi:10.1007/978-1-62703-764-8_17.

122. Quinn JY, Cox RS, Adler A, Beal J, Bhatia S, Cai Y, et al. SBOL Visual: a Graphical Language for Genetic Designs. PLOS Biol. 2015;13:e1002310.

123. Luo Y, Enghiad B, Zhao H. New tools for reconstruction and heterologous expression of natural product biosynthetic gene clusters. Nat Prod Rep. 2016;33(2):174-82.

124. Baek CH, Liss M, Clancy K, Chesnut J, Katzen F. DNA assembly tools and strategies for the generation of plasmids. Microbiol Spectr. 2014. doi:10.1128/microbiolspec.PLAS-0014-2013.

125. Kosuri S, Church GM. Large-scale de novo DNA synthesis: technologies and applications. Nat Methods. 2014;11:499-507.

126. Freestone TS, Zhao H. Combinatorial pathway engineering for optimized production of the anti-malarial FR900098. Biotechnol Bioeng. 2016:113:384-92.

127. Jeschek M, Gerngross D, Panke S. Rationally reduced libraries for combinatorial pathway optimization minimizing experimental effort. Nat Commun. 2016;7:11163.

128. Feng $X$, Zhuang W-Q, Colletti P, Tang YJ. Metabolic pathway determination and flux analysis in nonmodel microorganisms through ${ }^{13} \mathrm{C}$-isotope labeling. In: Navid A, editor. Microbial systems biology: methods and protocols. Totowa: Humana Press; 2012. p. 309-30. doi:10.1007/978-1-61779-827-6_11.

129. Du Y, Jiang W, Yu M, Tang IC, Yang ST. Metabolic process engineering of Clostridium tyrobutyricum ?ack-adhE2 for enhanced n-butanol production from glucose: effects of methyl viologen on NADH availability, flux distribution, and fermentation kinetics. Biotechnol Bioeng. 2015;112:705-15.

130. Du J, McGraw A, Hestekin JA. Modeling of Clostridium tyrobutyricum for butyric acid selectivity in continuous fermentation. Energies. 2014;7:2421-35.

131. Chen J, Gomez JA, Höffner K, Phalak P, Barton PI, Henson MA. Spatiotemporal modeling of microbial metabolism. BMC Syst Biol. 2016;10:21.

132. Chen J, Henson MA. In silico metabolic engineering of Clostridium ljungdahlii for synthesis gas fermentation. Metab Eng. 2016;38:389-400.

133. Lane J. Coskata's technology re-emerges as Synata Bio : biofuels digest. 2016. http://www.biofuelsdigest.com/bdigest/2016/01/24/ coskatas-technology-re-emerges-as-synata-bio/.

134. Sapp M. INEOS Bio selling 8 MGY demo plant in Florida : biofuels digest. 2016. http://www.biofuelsdigest.com/bdigest/2016/09/06/ ineos-bio-selling-8-mgy-demo-plant-in-florida/. 
135. Schill SR. Ethanol producer magazine-the latest news and data about ethanol production. 2013. http://www.ethanolproducer.com/articles/10096/ ineos-declares-commercial-cellulosic-ethanol-online-in-florida.

136. Global SCS. Beijing Shougang LanzaTech New Energy Science \& Technology Company Earns Roundtable on Sustainable Biomaterials (RSB) Certification. Newsroom. 2013. https://www.scsglobalservices. com/beijing-shougang-lanzatech-new-energy-science-technologycompany-earns-roundtable-on-sustainable.

137. Lane J. Virgin LanzaJet fuel: "A real game changer for aviation," says Branson. Biofuels Dig. 2016. www.biofuelsdigest.com/bdigest/2016/09/15/virgin-\%E2\%99\%A5-lanzajet-fuel-a-real-gamechanger-for-aviation-says-branson/. biofuels project. Biofuels Dig. 2015; www.biofuelsdigest.com/bdigest/2015/04/22/china-steel-green-lights-46m-for-commercial-scalelanzatech-advanced-biofuels-project/.

139. Lane J. Steel's Big Dog jumps into low carbon fuels: ArcelorMittal, LanzaTech, Primetals Technologies to construct $\$ 96 \mathrm{M}$ biofuel production facility. Biofuels Dig. 2015. http://www.biofuelsdigest.com/ bdigest/2015/07/13/steels-big-dog-jumps-into-low-carbon-fuels-arcelormittal-lanzatech-primetals-technologies-to-construct-96m-biofuelproduction-facility/.

\section{Submit your next manuscript to BioMed Central and we will help you at every step:}

- We accept pre-submission inquiries

- Our selector tool helps you to find the most relevant journal

- We provide round the clock customer support

- Convenient online submission

- Thorough peer review

- Inclusion in PubMed and all major indexing services

- Maximum visibility for your research

Submit your manuscript at www.biomedcentral.com/submit 